\title{
Factors Affecting Utah Ranch Prices
}

\author{
R.C. ROWAN AND JOHN P. WORKMAN
}

\begin{abstract}
Authors are graduate research assistant, Rangeland Ecology and Management, Texas A\&M University, College Station 77843-2126; and professor, Range Science Department, Utah State University, Logan 84322-5230. At the time of the research, Rowan was graduate research assistant at Utah State University.
\end{abstract}

\section{Abstract}

A total of 341 Utah rural land sales occurring between 1980 and 1987 were analyzed to identify and quantify the determinants of Utah rangeland and ranch prices. Two factors statistically influenced average sale price (\$/hectare and/or \$/AUM): number of hectares sold and whether buildings were included in the sale. Regression analysis incorporated statistically significant $(P<0.05)$ explanatory variables into a predictive equation that expressed total ranch sale price as a function of number of deeded AUMs, building value, year and month of sale, number of leased AUMs, distance to nearest town, recreation influence, and size of parcel sold. The regression model produced an adjusted $R^{2}=0.91$. Value of buildings and number of deeded AUMs explained most of the variability in total ranch sale price.

\section{Key Words: appraisal, valuation, model, regression, prediction}

A rural real estate appraiser may be asked to determine real estate equity positions, establish value for tax assessment, or determine value for condemnation hearings. Since appraisal is both a science and an art, appraisers use all available information to provide a value estimate. Any information that complements the traditional appraisal approaches may improve accuracy of estimates.

Demand for Utah farm and ranch land and resulting land prices increased from the 1940's until about 1982 (Fig. 1). Improved technologies allowed farmers and ranchers to own and rent more land without increased equipment inputs (Reynolds and Timmons 1969, Suter 1980, Scott 1983). Thus, demand for land remained strong during this period and economic theory predicted that the price of land should increase (Phipps 1984, Burt 1986). Land prices during the late 1970's did increase.

Inflation alone cannot explain the dramatic increase in land values in the late 1970's but does partially explain investment strategies during this period. Expectations of continued land appreciation induced investment and speculation. These expectations became a self-fulfilling prophecy, especially in 1979 and 1980 (Fig. 1).

The rural real estate market in the U.S. over the past 50 years has been marked by recurring price instability. Utah real estate values increased between 1975 and 1982 and then declined (Fig. 1). This paper attempts to identify and quantify the main factors influencing Utah rangeland and ranch prices.

\section{Methods}

Utah land sales that occurred betwen 1980 and 1987 and that were financed by Farm Credit Services (FCS) were analyzed to identify and quantify factors affecting Utah ranch prices. FCS is a leading source of rural real estate financing, second only to private sellers. Regional FCS offices keep detailed information on sales

\footnotetext{
Supported by the Utah Agricultural Experiment Station, Utah State University, Logan 84322-4845. Approved as journal paper 4143 . The authors appreciate helpful suggestions from associate editor Kirk McDaniel, reviewer Allen Iorell, and 2 ano nymous reviewers.

Manuscript accepted 4 September 1991
}

transactions. Information on a total of 341 FCS sales was obtained. Sample sales consisted of both whole ranches, including buildings and improvements, and unimproved tracts of cropland and rangeland. Characteristics of the ranch sales sample are shown in Table 1. Sales selected included those that had listed "establish own ranch" or "expand ranch operation" as reasons for purchase on the FCS sales forms. The small number of federal grazing permits transferred without land was not included in the study.

Table 1. Characteristics of the Utah ranch sales sample, 1980-87.

\begin{tabular}{lcr}
\hline Variable & $\begin{array}{c}\text { Number } \\
\text { of cases }\end{array}$ & Mean \\
\hline Sale price (\$) & 196 & 120,095 \\
Deeded hectares & 191 & 145 \\
Unit price (\$/ha) & 190 & 4,182 \\
Unit price (\$/AUM) & 98 & 391 \\
Deeded AUMs & 116 & 375 \\
Leased AUMs & 193 & 155 \\
Distance to town (kilometers) & 187 & 47 \\
Building value (\$) & 196 & 4,419 \\
Range hectares & 195 & 118 \\
Cultivated hectares & 180 & 19 \\
\hline
\end{tabular}

Ranch sales were analyzed to assess the importance of each individual price variable, independent of other price variables, using SPSS-X, Version 3.1 (Statistical Package for the Social Sciences 1989). A 5\% probability level was used for all statistical tests, except where indicated otherwise. Mean ranch prices $(\$ /$ ha and \$ (AUM), standard deviations, variances, standard errors, and the range of prices were calculated. Analysis of variance (ANOVA), group $t$-tests, and a Least Significant Difference (LSD) test were used to compare price differences among ranch sizes.

Mean values (\$/ha and \$/AUM) for ranches with and without buildings were compared across all sales to test whether there was a significant effect on sale price due to the presence of buildings.

The influence of nonranch variables (residential expansion, recreation potential, mineral reserves, and commercial development) was tested by $t$-tests across all ranch sales. Mean sale price (\$/ ha and \$/AUM) of all sales indicating some form of nonranch influence was compared to mean sale price of all sales with no nonranch influence.

FCS sales listing either "establish own ranch" or "expand ranch operation" as reasons for purchase were tested against sales listing any other reason for purchase. Both \$/ ha and \$/AUM comparisons were made.

Regression analysis was used to develop equations to predict and explain total ranch sale prices. FCS sales data provided the following information: total sale price; building value; number of cultivated, rangeland, and total hectares sold, sale price per hectare; livestock carrying capacity; reason for purchase, nonranch influence; and sale date. Various explanatory variables were evaluated to determine the model of best fit (highest R-squared and 


\section{Comparison of Utah Real Estate Index to Consumer Price Index}

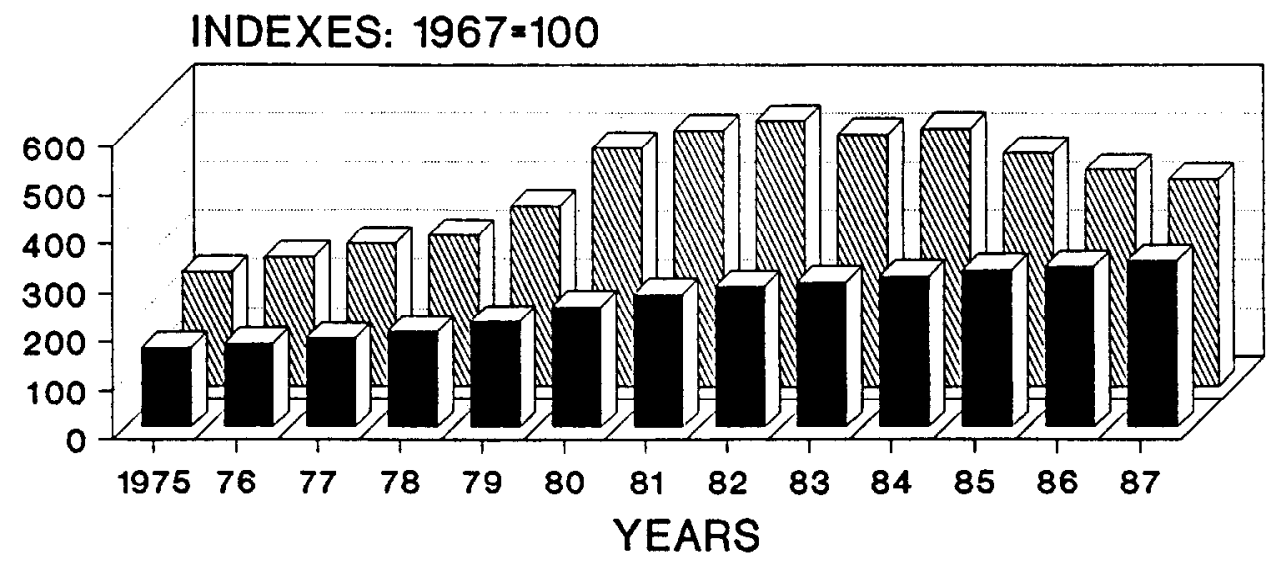

CPI 1/

MUTUW R.E. 21

1/ Statistical Abstract of the U.S.

2/ Farm Real Estate Market Developments

2/ Agricultural Resources

Fig. 1. Comparison of the Utah Real Estate Index (Utah R.E.) to the Consumer Price Index (CPI), $1975-87$.

appropriate algebraic signs of coefficients), and confidence of fit (significant $t$-tests). Consideration was also given to whether or not variables were readily available to model users. Explanatory variables considered for inclusion in the final model were: time, timesquared, total ranch hectares, number of deeded AUMs, number of leased AUMs, percent leased forage, dollar value of improvements, distance to a Utah town of at least 2,000 people, number of hectares deeded rangeland and pasture, number of cultivated hectares, quarterly FCS interest rates, Beef Cattle Price Index (BCPI), Prices Paid Index (PPI), a proxy index for net ranch income (BCPI-PPI) in the year of sale and also lagged 1 year from sale date, a productivity rating in deeded AUMs/deeded hectare, index (dummy) variables delineating 3 size categories $(<16,16-259$ and $>259 \mathrm{ha}$ ), and an index variable for nonranch influences. Predictive models were constructed by entering variables in forward step-wise multiple regression.

I he time variable was measured by month of sale with the median sale month (December, 1983) assigned the numerical value of zero. Sales prior to the median month were given consecutive negative values (e.g., October $1983=-2$ ) and those after were given consecutive positive values (e.g., February, 1984=+2).

Distance values were measured as the shortest distance along established roads from the ranch to a Utah town of at least 2,000 people (Andriot 1983). Measurements were to the nearest kilometer using the Sigma Scan (Jandel Scientific, Corte Mandera, Calif.) digitizing program.

Beef Cattle Price Indexes (BCPI) and Prices Paid Indexes (PPI) were from USDA (various issues, 1975-87). Since many of the sample sales were seasonal grazing tracts, carrying capacity was recorded in animal unit months (AUMs). Animal Units Year Long (AUYL) was also tested as an independent variable, defined as the total number of AUMs divided by 12 . Nonranch influence was entered into the analysis in binary form $(1,0)$, on the basis of presence or absence of influence. Quarterly interest rates were compiled from Boehlje and Eidman (1984), Melichar (monthly series, 1975-1987), and USDA (1988). the adjusted $R^{2}$ value was

Table 2. ANOVA table showing the effects of region and size (ha) on sale prices of Utah land (\$/ha), Farm Credit Services sales, $1980-87$.

\begin{tabular}{|c|c|c|c|c|c|}
\hline Source of variation & DF & Sum of squares & Mean square & $\mathrm{F}$ value & $P$ \\
\hline $\begin{array}{l}\text { Main effects: } \\
\text { Region of state } \\
\text { Size }\end{array}$ & $\begin{array}{r}4 \\
2 \\
2\end{array}$ & $\begin{array}{r}33,288,873,060 \\
7,473,748,023 \\
24,230,910,538\end{array}$ & $\begin{array}{r}8,322,218,265 \\
3,736,874,012 \\
12,115,455,269\end{array}$ & $\begin{array}{l}5.087 \\
2.284 \\
7.406\end{array}$ & $\begin{array}{l}.001^{*} \\
.105 \\
.001^{*}\end{array}$ \\
\hline $\begin{array}{l}\text { 2-Way: } \\
\text { Region } \times \text { Size } \\
\text { Residual }\end{array}$ & $\begin{array}{r}4 \\
185 \\
\end{array}$ & $\begin{array}{r}13,403,514,457 \\
302,634,899,082 \\
\end{array}$ & $\begin{array}{l}3,350,878,614 \\
1,635,864,319\end{array}$ & 2.048 & .089 \\
\hline Totals & $\overline{193}$ & $349,327,286,600$ & $1,809,985,941$ & & \\
\hline
\end{tabular}

*significant at the 0.05 level. 
reported for the final model following the methods of Verbyla (1986).

\section{Results and Discussion}

Farm Credit Services financed 341 ranch sales during the period 1980-87. There was considerable variability in size and other characteristics of the ranch sales sample (Table 1). Total deeded ranch hectares, for example, ranged from 1/2 ha to over 12,000 ha. Deeded AUMs ranged from 0 to 12,000 . Because the sample contained some very small sales, average unit values $(\$ /$ ha and $\$ /$ AUM) in Tables 3,4 , and 5 are skewed towards the high end of the range.

The mean price for agricultural land sales was approximately $\$ 120,000$ (Table 1). Mean hectares was 145 , composed of 118 ha of rangeland and pasture and 19 ha of cultivated land. The 8-ha balance was composed of building sites, homesites, and wasteland. In 1987, USDA (1985-88) listed the average size of "farms" in the mountain states region as 454 ha. The reason our sample Utah land sales were smaller than the regional average might be that the Utah sales included cropland parcels and small expansion tracts, thereby reducing the average parcel size.

Average deeded and leased AUMs for a 145-ha "ranch" totaled 530 AUMs. If this were a yearlong operation, the "ranch" would support approximately 45 AUYL. Again, many of these sales were probably expansion units.

\section{Size Effects}

Analysis of Variance (ANOVA) in Table 2 indicated that sale size significantly influenced $\$ /$ ha prices. The $F$-value for size indicated a significant difference among means but did not identify which sizes were different. A Least Significant Difference (LSD) test was performed on size means. Results indicated that size 1 $(\$ 26,035 /$ ha for parcels $<16 \mathrm{ha})$ differed significantly from both size $2(\$ 2,035 /$ ha for parcels $16-259 \mathrm{ha})$ and size $3(\$ 573 /$ ha for parcels $>259 \mathrm{ha})$.

\section{Building Influence}

Real estate salespersons and appraisers recognize the impact buildings can have on both total sale prices and unit prices. It is often generalized that highly improved acreages sell at a higher price $(\$ /$ ha or $\$ / A U M)$ than unimproved acreages. Average sale price (\$/AUM) was significantly ( 0.10 level) influenced by inclusion of buildings (Table 3). Further analysis indicated that at the

Table 3. Comparison of Farm Credit Services Utah ranch sale prices, with and without buildings, 1980-87.

\begin{tabular}{lrrrrrr}
\hline \hline & $\begin{array}{r}\text { \# of } \\
\text { Cases }\end{array}$ & Mean & $\begin{array}{r}\text { Std } \\
\text { Dev }\end{array}$ & DF & t-value & $\begin{array}{c}\text { 2-tail } \\
\text { P }\end{array}$ \\
\hline $\begin{array}{l}\text { Dollars Per Hectare: } \\
\quad \text { Without buildings }\end{array}$ & 163 & 10,652 & 46,016 & 154 & .94 & .35 \\
$\quad$ With buildings & 31 & 6,491 & 14,331 & & & \\
$\begin{array}{l}\text { Dollars Per AUM: } \\
\quad \text { Without buildings } \\
\text { With buildings }\end{array}$ & 77 & 767 & 2,857 & 79 & 1.65 & .10 \\
\hline
\end{tabular}

0.10 level there was a significant difference within size 2(16-259 ha) between sales with buildings (\$226/AUM) and sales without buildings (\$497/AUM). This higher average price without buildings was the reverse of what might be expected. It may be that buyers in this size category were most interested in additional land than in additional buildings.

\section{Nonranch influences}

Nonranch influences such as residential expansion, recreation potential, mineral reserves, and commercial development would be expected to affect the value of rural land. FCS appraisers noted the presence or absence of nonranch influence. Sales with nonranch influence were compared against those without such influence (Table 4). Nonranch influences did not significantly affect average sale prices (\$/ha or $\$ / A U M)$ at conventional levels of statistical significance, due to the large standard deviations.

Table 4. Comparison of Farm Credit Services Utah ranch sale prices, with and without nonranch influences, 1980-87.

\begin{tabular}{|c|c|c|c|c|c|c|}
\hline & $\begin{array}{r}\text { \# of } \\
\text { Cases }\end{array}$ & Mean & $\begin{array}{l}\text { Std } \\
\text { Dev }\end{array}$ & DF & $\begin{array}{c}\mathbf{t} \\
\text { Value }\end{array}$ & $\begin{array}{c}\text { 2-tail } \\
\mathbf{P}\end{array}$ \\
\hline $\begin{array}{l}\text { Dollars Per Hectare: } \\
\text { Without } \\
\text { influence }\end{array}$ & 160 & 10,353 & 46,448 & 172 & 48 & .64 \\
\hline $\begin{array}{l}\text { With } \\
\text { influence }\end{array}$ & 34 & 8,267 & 14,017 & & & \\
\hline $\begin{array}{l}\text { Dollars Per AUM: } \\
\text { Without } \\
\text { influence }\end{array}$ & 78 & 283 & 312 & 16 & -1.49 & .16 \\
\hline $\begin{array}{l}\text { With } \\
\text { influence }\end{array}$ & 17 & 2,414 & 5,886 & & & \\
\hline
\end{tabular}

\section{Reason for Purchase}

The final ANOVA was conducted to determine if reasons for purchase affected sale price. The relevant question was whether buyers purchasing land for agriculture paid a different price than buyers purchasing land for nonagricultural purposes. Nonagricultural reasons for purchase included investment, nonagricultural development, rural dwelling, other, and unknown. There was no significant difference ( .05 level) between average prices $(\$ /$ ha and \$/AUM) paid by agricultural buyers and nonagricultural buyers (Table 5). However, additional testing with the dependent

Table 5. Comparison of Prices of Farm Credit Services Utah ranch sale purchased for agricultural reasons with those purchased for nonagricultural reasons, 1980-87.

\begin{tabular}{lrrrrrr}
\hline & $\begin{array}{c}\# \text { of } \\
\text { Cases }\end{array}$ & Mean & $\begin{array}{c}\text { Std } \\
\text { Dev }\end{array}$ & DF & $\begin{array}{c}t \\
\text { Value }\end{array}$ & $\begin{array}{c}\text { 2-tail } \\
\mathbf{P}\end{array}$ \\
\hline $\begin{array}{l}\text { Dollars Per Hectare: } \\
\quad \text { Agricultural }\end{array}$ & 217 & 9,706 & 40,510 & 303 & .45 & .66 \\
$\quad \begin{array}{l}\text { Non-Agricultural } \\
\quad 120\end{array}$ & 8,333 & 15,092 & & & \\
$\begin{array}{l}\text { Dollars Per AUM: } \\
\quad \text { Agricultural }\end{array}$ & 110 & 784 & 2,774 & 48 & -1.32 & .19 \\
$\quad$ Non-Agricultural & 49 & 9,351 & 45,580 & & & \\
\hline
\end{tabular}

variable specified as total sale price per entire parcel showed a significant difference $(p=.026)$ between average total prices paid by agricultural buyers $(\$ 138,507)$ and nonagricultural buyers $(\$ 242,598)$.

\section{Predictive Equation}

A preliminary regression analysis was performed on a portion of ranch sales to identify a set of ranch price variables having predictive power. A forward stepwise regression of these sales yielded a reasonable fit $\left(R^{2}=.759\right)$.

Several restrictions were imposed on the data set to obtain a representative and normally distributed subsample. Various combinations of minimum sale size (acres and AUMs) proved unsatisfactory. Restrictions to ensure a normally distributed variance also gave an undesirably small sample size. These preliminary constraints were abandoned in favor of restricting the sample to sales for establishing or expanding a ranch. The purpose of the regression model was to accurately predict ranch prices based on price variables readily available to range managers and appraisers. The model could have been formulated with price per AUM (or price 
per acre) as the dependent variable (Torell and Doll 1990, Torell and Doll 1991). However, preliminary attempts using the price per AUM formulation resulted in equations with poor explanatory and predictive power. Consequently, total ranch price in nominal dollars was used as the dependent variable, following the approach of Torell and Fowler (1986), giving much stronger statistical results.

The final regression model was:

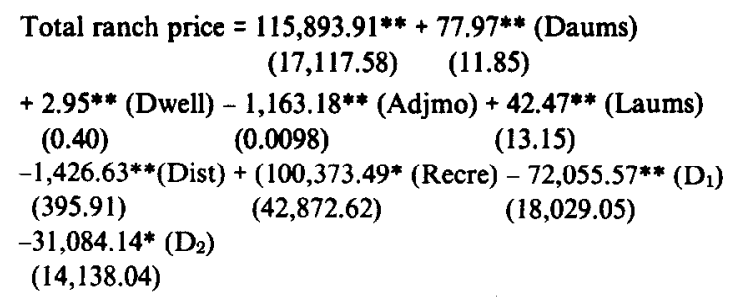

where

* = significant at 0.05 level, ** = significant at 0.01 level,

Daums $=$ Deeded animal unit months,

Dwell = Dwellings and buildings value,

Adjmo = Time trend variable for month of sale,

Laums = Leased animal unit months,

Dist = Distance to Utah town of 2,000 people (miles),

Recre $=1$ if recreational influence present,

$=0$ if recreational influence not present,

$D_{1}=1$ if size is $<40$ acres,

$=0$ if size is $40-640$ acres,

$=-1$ if size is $>640$ acres,

$\mathrm{D}_{2} \quad=0$ if size is $<40$ acres,

$=1$ if size is $40-640$ acres, and

$=-1$ if size is $>640$ acres.

Numbers in parentheses below coefficients are the standard errors of the coefficients. For ease of application by range managers and appraisers in the western U.S., all parameters are expressed in English units. This model is the result of regression of 82 sales (adjusted $R^{2}=.91$ ).

The final model explains $91 \%$ of the variability in sale price. It is also helpful to know which of the independent variables contributed the most towards predicting sale price. The "decomposition of the variability in Y" procedure (Gujarati 1988) was used and invovles the formula:

$\operatorname{SSReg}=\left({\beta_{2}}^{2} \mathrm{~m}_{22}+{\beta_{3}}^{2} \mathrm{~m}_{33}+\beta_{\mathrm{k}}{ }^{2} \mathrm{~m}_{\mathrm{kk}}\right)+2 \beta_{2} \beta_{3} \mathrm{~m}_{23}+\ldots .2 \beta_{\mathrm{j}} \beta_{\mathrm{k}} \mathrm{m}_{\mathrm{jk}}$

where $\beta_{2}, \beta_{3} \ldots . \beta_{\mathrm{k}}=$ explanatory variable coefficients

$\mathrm{m}_{22}, \mathrm{~m}_{33} \ldots \mathrm{m}_{\mathrm{kk}}=\mathrm{SS}$ of explanatory variables

$m_{23} \ldots . . m_{j k}=$ sum of cross products of variables.

The relevant portion of the equation (in parenthesis) is the individual contribution of each variable to the overall regression sum of squares (Table 6). Contributions of the interactions, which ac-

Table 6. Decomposition of explained variability in Utah ranch sale price for each independent variable in the model.

\begin{tabular}{lrrrr}
\hline \hline Variable & \multicolumn{1}{c}{ Total } \\
\hline Dwell & \multicolumn{1}{c}{${ }^{2}$} & \multicolumn{1}{c}{${ }^{2}{ }^{2} \mathrm{~m}_{\mathrm{ii}}$} & SSReg & Rank \\
Daums & 8.7 & $1.501597 \mathrm{E}+12$ & $22.80 \%$ & 1 \\
$\mathrm{D}_{1}$ & 6,079 & $1.414105 \mathrm{E}+12$ & $21.50 \%$ & 2 \\
Dist & $5.192005 \mathrm{E}+9$ & $1.739321 \mathrm{E}+11$ & $2.60 \%$ & 3 \\
Laums & $2,035,273$ & $1.700104 \mathrm{E}+11$ & $2.60 \%$ & 4 \\
Adjmo & 1,803 & $9.96575 \mathrm{E}+10$ & $1.50 \%$ & 5 \\
D $_{2}$ & $1,352,987$ & $6.564747 \mathrm{E}+10$ & $.98 \%$ & 6 \\
Recre & $966,223,760$ & $6.038898 \mathrm{E}+10$ & $.92 \%$ & 7 \\
SSReg & $1.007483 \mathrm{E}+10$ & $5.540000 \mathrm{E}+10$ & $.84 \%$ & 8 \\
\hline
\end{tabular}

$\mathrm{m}_{\mathrm{ii}}=$ matrix of sums of squares and cross-products counted for $38 \%$ of the explained variability of $\mathrm{Y}$, were not calculated.

Dwellings and buildings contributed the largest percentage to explained variability in total sale price. Thus, the real estate profession may be correct in attributing such importance to dwellings and buildings when estimating property values.

Regression coefficients for deeded and leased AUMs are close to expected values. To determine the estimated value of deeded land in dollars per Animal Unit Year Long, holding all other variables constant, the deeded AUM coefficient was multiplied by 12. Estimated value of deeded land was $\$ 935 / A U Y L$. The predictive equation estimated leased AUM values, all else equal, at \$42.47/AUM. This federal grazing permit value is similar to the one calculated by Workman (1988).

Users of the model must be cautioned that coefficient values cannot be extracted from the model and used independently without explicitly recognizing that all other variables are being held constant. Also, deletion of any variable will change coefficient values for remaining variables.

\section{Literature Cited}

Andriot, J.L. 1983. Population abstract of the United States. Andriot Associates, McLean, Va.

Boehlje, M.D., and V.R. Eidman. 1984. Farm management. John Wiley and Sons, N.Y.

Burt, O.R. 1986. Economic modeling of the capitalization formula for farmland prices. Amer. J. Agr. Econ. 66:10-26.

Gujarati, D.N. 1988. Basic econometrics. McGraw-Hill Book Co., N.Y.

Melichar, E. 1975-87, monthly series. Agricultural finance datebook. Division of Research and Statistics. Board of Governors of the Federal Reserve System, Washington, D.C.

Phipps, T.T. 1984. Land prices and farm based returns. Amer. J. Agr. Econ. 66:422-429.

Reynolds, T.E., and J.F. Timmons. 1969. Factors affecting farmland value in the United States. Iowa State University Agr. Exp. Sta. Bull. 566.

Scott, J.T., Jr. 1983. Factors affecting land price decline. Amer. J. Agr. Econ. 65:796-800.

Statistical Package for the Social Sciences. 1989. Version 3.1. SPSSX, Inc. Chicago, Ill.

Suter, R.C. 1980. The appraisal of farm rest estate. Interstate Printers and Publ., Inc., Danville, Ill.

Torell, L.A., and J.M. Fowler. 1986. A model for predicting trends of New Mexico grazing land values. New Mexico State University Agr. Exp. Sta. Res. Bull. 723.

Torell, L.A., and J.P. Doll. 1990. The market value of New Mexico Ranches, 1980-88. New Mexico State Univ. Agr. Exp. Sta. Bull. 748.

Torell, L.A., and J.P. Doll. 1991. Public land policy and the value of grazing permits. Western J. Agr. Econ. 16:174-184.

USDA. 1975-1987, various issues. Agricultural prices. Nat. Agr. Stat. Serv., Washington, D.C.

USDA. 1984. Farm real estate market developments. Econ. Res. Serv., Washington, D.C.

USDA. 1985-88, various issues. Agricultural resources. Econ. Res. Serv. Washington, D.C.

U.S. Department of Commerce. 1975-87, various issues. Statistical abstract of the United States. National data book and guide to sources. Bureau of the Census, Washington, D.C.

USDA. 1988. Economic Research Service: FINDERS, Advisory System (V89.10) Release 3.63, Ist Class Expert Systems, Inc., Washington, D.C.

Verbyla, D. 1986. Potential prediction bias in regression and discriminate analysis. Can. J. Forest. Res. 16:1255-1257.

Workman, J.P. 1988. Federal grazing fees: a controversy that won't go away. Rangelands 10:128-130. 